\title{
Ellen-Fairbanks Diggs Bodman
}

1924-2007

Ellen-Fairbanks Diggs Bodman, Taffy to those who KNew her well, passed away on July 7, 2007 in Chapel Hill, North Carolina. Taffy was born on September 2, 1924, in Waterville, Maine, and grew up first in Virginia, then Massachusetts. She graduated from Smith College in 1945 with a double major in history and musicology, and as a member of Phi Beta Kappa. Taffy went on to receive a master's degree in American history at the University of North Carolina, Chapel Hill, where she became an instructor in 1946. In one of her classes she met Herbert Bodman, an undergraduate history major newly returned from military service. They married in 1947.

It is at this point that Taffy's association with the Middle East began. Her path in some ways parallels the development of Middle East studies in the United States. The late 1940s and 1950s found her and Herb at Princeton University, where he did his doctoral work in Islamic history and she audited classes in Arabic and Turkish. They moved to Lebanon and the American University of Beirut, then Montréal and McGill University; at both institutions Taffy taught English to international students while Herb taught History. They subsequently lived in Washington, D.C., where Herb worked at the U.S. Information Agency. Their four children were born during the years of the family's peregrinations. The family moved to North Carolina in 1960 when Herb got a job at the University of North Carolina at Chapel Hill. Taffy taught Western Civilization at North Carolina Central University for some time. Taffy's abundant energy benefited many local community organizations, especially the Chapel Hill Public Library and the Carolina Dispute Settlement Center. She was also much involved in Middle East studies. In 1977 she and Herb were among the founders of the Southeast Regional Middle East and Islamic Studies Seminar (SERMEISS)-a vibrant regional organization and MESA affiliate to which they remained devoted, and that continues to bring together Middle East studies scholars.

Taffy was a dedicated founding member of the Middle East Outreach Council (MEOC), a national network of educators established in 1981 to exchange information on Middle East outreach and to promote the sharing of information, resources, and activities about the Middle East, particularly among non-specialists at the K-12 and college levels. She drafted MEOC's 
bylaws, and served as MEOC parliamentarian. She also authored outreach materials, including the Middle East Master Map Kit: Their Lands and Ours (1989).

When Herb became director of the American Council of Learned Societies' Islamic Teaching Materials project, Taffy developed an interest in documentary films about the Middle East and edited the project's first publication: The World of Islam, Images and Echoes: A Critical Guide to Films and Recordings (1980), which included a filmography and discography.

Her interest in films led her to organize the first MESA meeting film program in 1984, a task she continued to perform with remarkable energy and enthusiasm through 2002. During the last two years, the task was gradually relinquished to MESA staff under her tutelage. The film program's organization continues to bear her imprint. Taffy's close association with films about and from the Middle East and with filmmakers remains evident in the MESA FilmFest and in the extensive Ellen-Fairbanks D. Bodman Collection of Middle Eastern and Islamic World Films at the University of North Carolina Libraries' Media Resources Center, University of North Carolina (http://www.lib.unc.edu/house/mrc/pagescollection/bodman. html), in many respects her offspring.

Taffy and Herb were instrumental in bringing the MESA conference to Research Triangle Park, North Carolina in 1993. Taffy's significant contributions to MESA, Middle East outreach, and the field of Middle East studies were recognized by her receipt of one of two inaugural MESA Service Awards in 1997 and her election to the MESA Board of Directors, on which she served from 1999-2001.

Ellen-Fairbanks Bodman's memory lives on in the hearts of her many friends and admirers, some fortunate to have enjoyed delicious meals in her home and tasty tokens of her esteem-small jars of delicious jam among them-that she brought to colleagues at conferences. She once bestowed a bejeweled shoehorn on MESA staff to help them squeeze yet one more event into an already packed program. Taffy brought fun and keen intelligence, as well as small treasures, to all that she did. Her greatest gift was herself. Ellen-Fairbanks Bodman's presence is sorely missed in Middle East studies gatherings, which were much the better for her discerning eye, unstinting attention, and generosity of spirit. $\%$

Anne H. Betteridge University of Arizona 